\title{
Civics Learning for Building Smart and Good Citizenship Characters In High School Level
}

\author{
Sarilan $^{1}$, Nunuk Suryani², Muhammad Akhyar ${ }^{3}$, Hassan Suryono ${ }^{4}$ \\ 1,2,3,4Postgraduate History Education Program Universitas Sebelas Maret, Surakarta Indonesia \\ 1,2nunuksuryani@fkip.uns.ac.id, ${ }^{3}$ muhammadakhyar.uns@gmail.com, ${ }^{4}$ hassan suryono@yahoo.com
}

\begin{abstract}
Civics learning has the main topic of everything related to citizens whether they are rights and responsibility or role of the people. The learning aims towards the building of a good and responsible citizen based on Pancasila and UUD 1945 which means that it is also integrated with character education. Other than good and responsible, civics also aims to bring smart and good citizenship characters. To achieve that goal, the civics learning process is always to be developed positively and democratically. To realize smart citizens means that civics is a preparation towards the future of the generation who understands and practices the values of citizenship. Besides that, civics as learning also combines the original and local values of the Indonesian which is reflected by Pancasila as the nation's ideology.
\end{abstract}

Keywords: good citizen, smart, character, civics, learning

\section{Introduction}

In this era of Reformation, the youth ought to participate in the national building. As the nation's successor, the youth holds a big role to realize the nation which is superior, smart, and well-mannered following Indonesia's hope. To bring that wish into reality, an educated and qualified generation is needed. Therefore, since Independence Day until this time, the nation prioritizes the development of education [1] which concurs with the beginning of the National Act (UUD) 1945, the fourth paragraph which stated about the aim to raise the nation's intellectuality.

Based on UU No. 20 2003, Act 3, national education functions to build character and the nation's dignity. The national character becomes very important for the youth, especially amid the globalization stream these days since the foreign culture's negative influence affects the attitude and morality of Indonesians. National character education becomes urgent to strengthen identity as an Indonesian. Pangalila [2] mentioned that Indonesians right now are facing a de-characterization, proved by national problems. To solve the problems, he suggested that a combined policy that can accommodate national values is needed.

One form of educations which can build national character is civics. Civics becomes one among the obligatory majors, from elementary school to college level. Through civics, students are directed to become not only smart generation but also good citizens. Mahendra [3] mentions that civics is a major which focuses on the building of citizen who can understand their rights and responsibilities as Pancasila and UUD 1945 have stated.

Civics is a good means to instill national character values [2]. This learning has a strategic role in sustaining the nation's life since it can build the youth to become serious in keeping national unity and integrity. In accordance, Mahendra [3] stated that civics holds a role to instill democratic attitude, national values, and keeps the national character. To build a smart 
generation is indeed a nation's hope, but it should never neglect the national character. civics fills this gap as learning which realizes the nation's wish to build a smart and responsible citizen.

\section{Method}

This article is descriptive research with a qualitative approach. The researcher in this inquiry acts as the main instrument [4]. The data for this research is collected through a literature study. As of the analysis technique, this research employs the Interactive Analysis method in which the process is: data collection, data reduction, data presentation, and verification/conclusion [5].

\section{Results And Discussion}

\subsection{Definition of Civics}

Pancasila and Citizenship Education or civics is a course that teaches about citizenship, law, norms, and national values. The learning also extends into some topics regarding rights, responsibilities, and their roles, as it is stated in Pancasila and UUD 1945. Based on the Constitution of National Education System Number 2 1989, act 39, civics has two major roles. First, it is a means to give students base knowledge about the relationship between a citizen and his country. Second, civics is a preliminary education of national defense.

The main purpose of civics is to form a good citizen, be it is toward their God, country, and their fellow under life view and Indonesian national value. According to Suradi [6], as one among social sciences, civics emphasizes the values of virtue and patriotism. In the practice, civics is designed to develop student's critical thinking ability, directed to form a national character that is smart, participative, and responsible. As time goes by, civics' goal also extends to form a smart citizen. Thus, it would result in the form of a generation who can face dynamic life challenges and solve problems while making good decisions for themselves, the people, and the country.

Dimyati [7] stated that there are three main purposes in civics which are civic intelligence, civic responsibility, and civic participation. In this case, building a smart city means that they should have a decent mindset and character, especially for the youth who should take their responsibility as a good citizen. With that, the young generation can actively participate in the life of the people, the nation, and the country. This view is also in concurrence with Shelina [8] who said civics is a major which aims to develop values through democracy.

The main components in civics, as mentioned in Civic for Civic Education of 1994, is knowledge of citizenship, civic skill, and civic disposition [9]. Those three components are tied to each other. A citizen at first must possess a good knowledge of civic. After he has grasped about it well, he should have civic skills that he applies in his social and national life. At last, the knowledge and skill will turn into a character that becomes attitude and habit.

According to Winarno (2012: 59), smart and good citizenship is the joining point between civic confidence, civic competence, and civic commitment. Civic trust comes from civic knowledge and civic disposition. Civic competence is a slice of civic knowledge and civic skill. Civic commitment comes from the civic disposition and civic skill. Therefore, it means 
that a smart and good citizen is one who possesses civic knowledge, civic disposition, and civic skill. Civic knowledge is an academic-scientific ability to understand the rights and obligations of the citizen. Various concepts and theories from politics, morals, and law are used to develop this knowledge. Civic skill is the ability of a citizen to solve various national issues using his civic knowledge. Civic disposition is a substantive characteristic that comes from civic knowledge and civic skill that is acquired and learned by a citizen (Mulyono, 2017: 220).

Civics learning also serves as value education by internalizing Pancasila values and Indonesian culture [10]. As an obligatory major at school, civic has a role to instill, build, strengthen, and preserve humanity and national life principles. In that, civics drives the students to have a mindset and attitude as humane citizens. This proves that civics is a good choice to internalize national character values [2]. And as stated prior, the mindset and attitude will become an identity which of every citizen, practiced every day.

\subsection{Building Smart Character and Good Citizen Through Civics Learning}

The term character has a meaning as the behavior or personality of a person which becomes something which differs from other people [11]. It needs a long time to form a person's character. In this case, education becomes the right way to build character. Thus, character education can help a person in thinking or behavior, and deciding their life.

The Pancasila and Citizenship Education or Indonesian civics has a mission to develop character education. Civics has become a way which provides values, attitude, and norms through learning. This learning is developed by placing character as the learning result which forms a student's attitude. This role is strategic in instilling life principles of national character as a good citizen [3]. The national character itself is a citizen's character which puts high regard towards the diversity of life in Indonesia [11].

The true nature of civic education is to improve the quality of the citizen through education. Education has an important role to cultivate the nation's character. The nation's character referred here is the dignified character of Indonesian citizens that uphold the democratic values to their nation and state life, according to Pancasila, UUD 1945, and social norms. In other words, civic education carries a mission to build the nation's character. The education itself also becomes a socio-cultural mode to construct a democratic life. Izma and Kesuma (2019: 90-91) stated that there are several values as nation's character that could be the indicators to develop the character of the young generation according to Kemdiknas (2010) such as religious, honesty, responsibility, tolerance, discipline, hard work, creative, democratic, nation spirit and love to the homeland, and attention to social and the environment in general.

Civics as an integrated major with character education has an important task to form good citizen character. The Pancasila and Citizenship education teaches the importance of rights and responsibilities of a citizen-based on the nation's hopes and goals. This is in concurrence with the target of civics in which Indonesians able to become good and smart citizens [8]. To achieve that goal, the process of civic learning is supported by character values, positively and democratically. A good and smart citizen is someone who understands all of their rights and responsibilities based on Pancasila and UUD 1945. Therefore, the main aim of civics is the teaching of attitude, skill training for democracy, obedience in law, and rules in social life [9].

As the goal of education, the main purpose of civics is also to intellectualize the citizen. To become intellectual means that someone understands and practices values as a citizen so that society accepts him [11]. Furthermore, a good and smart generation is those who can stand on 
their own identity and respects others. This kind of smart is not the only intellectuality, but also includes emotional and spiritual aspects which complement each other.

As a part of Indonesia's national education means, civic education is focusing on developing both good and smart citizens. This is following the attachment of Permendikbud No. 22 of 2006 which states that civic education is a course that focused on developing the Indonesian citizen to understand and carrying out their right and obligation as intelligent, skilled, and dignified beings according to the mandate in Pancasila and the 1945 Constitution. Akbal (2016) stated that the term smart in civic context is to think and behave intelligently both in solving problems and in making the right decisions in the context of civic, nationality, and society. This is the role of civic education to give the intellectual, emotional, social, and spiritual knowledge to all of the citizens.

Besides building smart citizens, civic also has a purpose to realize good citizens which incorporates cultural values. Pancasila as the national ideology in itself has contained Indonesian cultural values and civics will become the media for conveying them. The cultural values which are also called civic disposition are the ideal character for the citizen which moves the people to become good citizens [8]. The democratic attitude is the aspect that supports the civic disposition of the people. This character has a great role in building a responsible citizen who participates in the public affair and political life [8].

Concerning the building of good citizens, civics utilizes a value-based approach that puts stressing on transferring values. The values are based on the Indonesian culture, contained in Pancasila. This form of moral education has a goal to build the students to become a good citizen, based on the nation's cultural values. Thus, the learning of civics can become an education media to build national character [12].

It should be underlined that although related, civic education with character education has a different focus. Winarno (2012: 59) described that civics is a part of the wide definition of character education. Civics emphasizes on developing the character of an individual in association with citizenship. Meanwhile, character education focuses more on developing an individual character which is inherent to a person. In other words, civic education is not the only form of character education. Civic education aims to form good citizens, while character education aims to shape a good person, as an individual. The term 'good citizen' is certainly different from the term 'good person'. A good citizen is based on the constitution of the corresponding country, while a good person is based on conscience and moral obligations (Winarno, 2012: 59).

Civics as citizenship education possess a wider meaning. In a broader definition, citizenship education is not restricted in the formal aspects of civic but also includes various ideas from society. The goal is none other than to develop a good and smart citizen in all levels of education [12]. The scope of education in this case also includes learning outside school or in society.

Related to formal education, civics in high school level is an ideal way to build a student's character. Students of high school level have a suitable age for understanding and applying civic values deeply. This stage of age is a crucial period for developing roles and responsibilities as a citizen [9]. They should begin to actively participate in their role as part of the country. Besides that, high school age is a phase where youths start to think critically about their environment and they are bound to take bigger responsibilities as part of the society and the nation as a whole. Therefore, civics or citizenship education becomes very important for high school students to prepare them to become good citizens.

As mentioned by Pangalila (2017: 91), currently, Indonesia is facing various national problems such as corruption, violence, fanaticism, and some more. These various issues occur 
due to the deterioration in character and uncertainty in the national identity of Indonesian citizens. This situation seems to be getting more complicated due to the strong current of globalization and the times that causing the decline of Pancasila character in Indonesia's young generation. If we analyze more further, it can be seen that the main cause is that the values of Pancasila have not been fully lived and practiced and the awareness of the nation's cultural values is increasingly fading. If this situation continues, the confidence in the strength and character of the nation will gradually collapse. Therefore, through civics learning, every citizen is expected to be able to increase their awareness and responsibility as a good citizen.

Civics learning in essence is an effort to build a good citizen for the future. The young generation is the main target since they should take the role and responsibility as a good citizen of the coming era. A good citizen according to UU Number 2, 1989 is a citizen who actively participates in building the country to become democratic, humanistic, and socially just. When the civics goal to build smart and good citizens is achieved, a superior generation also comes. As a citizen, a person should become useful for the nation and country while facing the future challenges. In this Reformation era, good citizens are people who support the realization of a prosperous society. Through civics, the intellectuals of Indonesia hopefully have a personality that is democratic, religious, humanistic, and civilized.

\section{Conclusion}

Education is a means to prepare the superior and qualified next-generation following the hope of Indonesians. The nation's coming generation should be a generation that has a national character based on Pancasila and UUD 1945. UU Number 20, 2003 about the National Education System stated that national education has the purpose to develop skills and build national dignified character. The character is the original values based on Indonesian culture. These values become the foundation to build and prepare good citizens where they are taught to think, act, and take decisions for their lives in society and country.

Pancasila and Citizenship Education or civics is a major for building character. The learning has the main goal for building smart and good citizens. With such a mission, civics has a strategic role for the nation's life since it prepares the next generation who commits to defending the unity and national integrity.

As one of many majors in high school, civics has an important role to instill national character values. The high school level is an ideal stage for students to understand and apply the values of civic deeply. Civics as a course at this point becomes very important for preparing the youths in order, they can take their role and responsibilities as citizens.

\section{References}

[1] Rianto, Hadi. (2015). Peran Pendidikan Pancasila dan Kewarganegaraan Membangun Generasi Cerdas dan Berkarakter. Sosial Horizon: Jurnal Pendidikan Sosial, 2 (1), 14-21.

[2] Pangalila, Theodorus. (2017). Peningkatan civics Disposition Siswa Melalui Pembelajaran Pendidikan kewarganegaraan (PKn). Jurnal Pendidikan Kewarganegaraan, 7 (1), 91-103.

[3] Mahendra, Putu Ronny Angga. (2017). Peran Strategis PKn Untuk Membangun Karakter Bagi Mahasiswa. Jurnal Kajian Pendidikan Widya Accarya FKIP Universitas Dwijendra, 8 (2), 1-8.

[4] Creswell, John W. (2014). Research Design: Qualitative, Quantitative, and Mixed Methods Approaches. Singapore: SAGE. 
[5] Miles, B. Matthew \& Huberman, A. Michael. (1992). Analisis Data Kualitatif: Buku Sumber Tentang Metode-Metode Baru. Terjemahan: Tjetjep Rohendi Rohidi. Jakarta: UI Press.

[6] Suradi, L. (2020). Pendidikan Kewarganegaraan Sebagai Pendidikan Nilai dan Pendidikan Hukum dalam Mewujudkan Warga Negara Yang Cerdas dan Baik (Smart and Good Citizen). Supremasi: Jurnal Pemikiran dan Penelitian Ilmu-Ilmu Sosial, Hukum, \& Pengajarannya, 14 (2), 112-121.

[7] Dimyati, H. Endang. (2017). Pembelajaran PKn Berbasis Kontekstual Bagi Penguatan Karakter Bangsa. Journal civicss \& Social Studies, 1 (1), 1-11.

[8] Shelina, et al. (2019). Peran Pembelajaran PPKn dalam Membentuk Sikap Demokratis Untuk meningkatkan civics Disposition Siswa. Jurnal Fakultas Keguruan dan Ilmu Pendidikan UNILA, $5(2), 1-13$.

[9] Ikhtiarti, et al. (2019). Membangun Generasi Muda Smart and Good Citizenship Melalui Pembelajaran PPKn Menghadapi Tantangan Revolusi Industri 4.0. In: Seminar Nasional Pendidikan FKIP 2019, 3 Januari 2019, FKIP Universitas Lampung.

[10] Totok, Tolak. (2017). Pembelajaran Pendidikan Pancasila dan Kewarganegaraan Berbasis Kearifan Lokal Untuk Penguatan Karakter dan Jati Diri Bangsa. Prosiding Konferensi Nasional Kewarganegaraan III, 11 November 2017, Universitas Ahmad Dahlan, Yogyakarta.

[11] Ananda, Azwar. (2012). Pendidikan Kewarganegaraan dan Pendidikan Karakter Bangsa. Jurnal Demokrasi, 11 (1), 258-283.

[12] Saputra, Edi. (2012). Eksistensi PKn Sebagai Pendidikan Nilai Dalam Membangun Karakter Bangsa. Jurnal Tingkap, 8 (2), 145-158. 